\title{
New Strategies and Measures for College Engineering Education under the Framework of Professional Engineering Accreditation
}

\author{
Guoqing Yu, Jing Lv, Shuanghua Cao \\ School of Environment and Architecture \\ Shanghai University for Science and Technology \\ Shanghai, China \\ E-mail: yuguoqinghvac@163.com
}

\begin{abstract}
Engineering accreditation is an important foundation for building international mutual recognition of engineering education and engineer qualification. This paper introduces the engineering accreditation and the Washington Accord at first. Then, according to the professional evaluation practice for some engineering programs in China, the paper proposes two strategies to carry out engineering accreditation on the basis of professional evaluation. Finally, some suggestions and measures for the college engineering education in China are proposed to adapt to engineering accreditation: (1) More measure should be taken to students' communication, teamwork and engineering ethics while teaching students engineering knowledge, (2) The relationship between college engineering education and industrial sector should be more closely integrated and the ability of engineering application should be strengthened (3) The teaching staff should be optimized according to the engineering accreditation standards; (4) The students' global vision and international competitiveness should be developed.
\end{abstract}

Keywords-College Engineering Education; Engineering Accreditation; Professional Assessment

\section{INTRODUCTION TO ENGINEERING ACCREDITATION}

\section{A. The Status of Engineering Accreditation in China}

Engineering education accreditation is an important foundation for building international mutual recognition of engineering education and engineer qualification. From 2005 onwards, China gradually carried out accreditation in the engineering degree programs. After nearly 10 years of development, China has accredited 18 of the whole 31 engineering majors. At the end of 2015, over 553 programs have received accreditation.

China Engineering Education Accreditation Association, directed by the Ministry of Education of China, was founded in October 2015, with mechanical, computer, water conservancy, environment, electrical and electronics, materials and other 14 sub-committees [1]. It is mainly responsible for the implementation of engineering education accreditation in China. The association currently has 33 group members and some individual members. Group members cover the major

The research is supported by Teachers' Teaching Development Research Project of University of Shanghai for Science and Technology. national industry associations and professional engineering society, such as Chinese Mechanical Engineering Society, China Computer Federation, China Association of Higher Education, etc. The individual members are mainly from the relevant leadership of the Ministry of Education of China, Ministry of Human Resources and Social Security of China, Ministry of Housing and Urban-Rural Development of China, China Association for Science and Technology and Chinese Academy of Engineering, as well as leaders and experts of some colleges and universities, industry organizations and enterprise.

\section{B. Washington Accord}

On 2 June 2016, the Washington Accord admitted the China Association for Science and Technology (CAST) as a full signatory [2]. The Washington Accord is the most influential mutual recognition of engineering qualifications among the world, whose purpose is to achieve mutual recognition of engineering degree and to promote the international mobility of engineers and technicians through the results of multi-lateral recognition of engineering education accreditation. After 20 years of development, currently there are nineteen signatories that make up the Washington Accord, including China, the United States, Britain, Canada, Australia, South Africa, Japan, Korea, Russia, India etc. China's participation in the Washington Accord means that the engineering accreditation is of international substantive equivalence and the results of our engineering education accreditation is recognized by other signatories. The graduates, who graduate from universities that have received the engineering education accreditation, when they apply for engineer qualifications in other signatory countries will have the same treatment as their graduates. This will greatly promote the reforms of education and teaching in universities in accordance with international advanced concepts and accelerate the integration of universities.

\section{Accreditation Processes}

\section{1) Application and acceptance}

In accordance with the relevant regulations of the Ministry of Education of China, the engineering undergraduate majors, 
which have at least three graduate priors to the academic year when the on-site review occurs, can apply for accreditation. Degree-granting institutions (colleges and universities) should submit the application to the secretariat. After receiving the application, the secretariat will review it. According to the audit situation, there are two conclusions: be accepted or not be accepted, and the corresponding treatment should be done.

2) Self-assessment and submission of self-assessment report

According the 'engineering education accreditation standards', the institution should conduct a serious selfexamination about the running situation of the engineering degree programs and teaching quality. The institution should write and submit self-assessment reports based on selfassessment.

\section{3) The review of the self-assessment report}

The accreditation committee reviews the self-assessment reports submitted by the degree-granting institutions, and focuses on whether the engineering degree programs meet the requirements of the "engineering education accreditation standards". According to the review situation, some conclusions can be made: 1) pass the review; 2) supplement the self-assessment report; 3 ) does not pass the review.

\section{4) On-site investigation}

The accreditation review team which is assigned by the accreditation committee will go to the degree-granting institutions where the engineering degree programs is located. The main purpose of the on-site investigation is to verify the information provided in the self-assessment report and to assess factors that cannot be adequately described in the selfassessment report.

\section{5) Deliberation and the accreditation decision}

The deliberation includes procedures such as school opinion consultation, the deliberation of accreditation committee, the deliberation of accreditation conclusion committee and the council approves and publishes the accreditation conclusions. There are three kinds of accreditation conclusions: 1) pass the accreditation, valid for 6 years; 2) pass the accreditation, valid for 3 years; 3 ) does not pass the accreditation.

\section{6) Maintain and improve the status of accreditation}

The degree-granting institutions where the accredited engineering degree programs is located should carefully study the problems and shortcomings identified in the report and take effective measures to improve them. If you want to maintain the continuity of the validity of the accreditation period, you must reapply the application for accreditation at least one year before the expiry date of the accreditation period.

Under the background of engineering accreditation, this paper proposes some strategies and measures for the college engineering education in China.

\section{THE INTEGRATION OF PROFESSIONAL ASSESSMENT AND ENGINEERING ACCREDITATION}

China has been carried out engineering accreditation for only 12 years and became a signatory in Washington Accord last year. We don't have much experience on engineering accreditation compared to other countries. But the professional assessment for engineering education has been carried out for many years. For example, the professional assessment for Civil Engineering was carried out in 1995 [3]. The professional assessment, which the Ministry of Housing and Urban-Rural Development of China (MOHURD) is in charge of, mainly focuses on six majors such as Architecture, Urban Planning, Civil Engineering, Water Supply and Sewerage Engineering, Building Environment and Energy Engineering and Engineering Management.

As for July 2017, there have been 92 institutions in Civil Engineering, 39 institutions in the Building Environment and Energy Engineering, and 38 institutions in the Water Supply and Sewerage Engineering passed the professional assessment. There is already a complete and mature assessment system in the field of Civil Engineering. The process of Professional assessment is basically same as engineering accreditation. They both include application, self-assessment, on-site investigations, conclusions and continuous improvement. So, it is the trend to carry out engineering accreditation on the basis of professional assessment. There are two ways:

\section{A. Combine Professional evaluation with engineering accreditation}

The process of Professional assessment is basically same as engineering accreditation, so it is feasible to combine them into one. There were some attempts have been done in China.

On 21 June 2017, MOHURD published a series of documents [4], such as "National College Education Civil Engineering Assessment (Accreditation) Document" (2017, 6th Edition), "National College Education Engineering Management Assessment (Accreditation) Documents (for Engineering Management and Construction Cost)" (2017, the third edition), and " National College Education Water Supply and Sewerage Engineering Assessment (Accreditation) Documents " (2016, trial version). According to these documents, we can find that the standards and process of the professional assessment were revised based on the requirements of engineering accreditation. The validity of Civil Engineering and Water Supply and Sewerage Engineering was 5 years. It has been modified. There are three kinds of assessment (accreditation) conclusions: 1) pass the assessment (accreditation), valid for 6 years; 2) pass the assessment (accreditation), valid for 3 years; 3) does not pass the assessment (accreditation).

\section{B. Retain the Professional Assessment and Build an Interoperability Mechanism with the Engineering Accreditation}

The purpose and role of professional assessment and engineering accreditation is still different. The purpose of professional assessment is to assess the quality of universities and its core purpose is to improve the level of education of university. But the key role of engineering accreditation is to achieve mutual recognition of engineering degree with other countries. The key importance of engineering accreditation is the effectiveness and uniformity of accreditation conclusions 
among other signatories. If the level of accreditation of a country is obviously lower than other countries, it will seriously affect the level of accreditation of all signatories and affect the mutual recognition of accreditation.

The current task is to do some researches about the level of engineering degree programs that has been accredited by the Washington Accord signatories. Especially we should know whether the curriculum system is set in the same way and students' mastery of the professional knowledge to determine the benchmark of accreditation in our country, and promote the engineering accreditation.

We can consider the classification of certification conclusions for professional assessments, such as A, B, C. Grade $\mathrm{A}$ is equivalent to an accredited 6-year period of engineering accreditation. Grade B is equivalent to an accredited 3-year period. And if you get Grade C, that means you pass the professional assessment but do not pass the engineering accreditation. This way can retain the characteristics of professional evaluation and have greater flexibility. While maintaining professional assessment and engineering certification, more institutions can be integrated into the professional assessment supervision system.

\section{THE COLLEGE ENGINEERING EDUCATION UNDER THE FRAMEWORK OF ENGINEERING ACCREDITATION}

\section{A. The Requirements for Students by Engineering Accreditation}

The mainstream idea of international engineering education is that students should have a view of 'Big Engineering'. The traditional engineering education in China pay more attention to the engineering knowledge and technical ability of graduates, and always overlook communication, teamwork and ethics, which are usually key points that employers focus. The key features of the graduate attributes are summarized in the engineering accreditation standards. Students should have an ability to apply knowledge of mathematics, science, and engineering to solve the problem. For the complex problems, student not only can use first principles of mathematics, natural sciences and engineering sciences to analyze them, but also can create, select and apply appropriate techniques, resources and modern engineering and IT tools, including prediction and modelling, to complex engineering problems, with an understanding of the limitations. An understanding of professional and ethical responsibility and an ability to communicate effectively are also important for the students.

\section{B. University Education and the Industry Should to be More Closely Integrated and the Cultivation of Engineering Practice Ability Should be Strenghened}

\section{1) Training objectives}

The training objectives reflect the achievements that are expected to be achieved in the social and professional fields about five years after graduation. Industry or business experts should be involved in evaluation and revision process.

\section{2) Curriculum system}

The curriculum system is designed with the participation of enterprises or industry experts.

3) Engineering practice and graduation design (paper) (at least $20 \%$ of total credits).

We can build up a complete practical teaching system and cooperation with enterprises to develop students' practical ability and innovation ability. Graduation design (thesis) topics should be combined with practical engineering problems of the major, to develop students' engineering awareness, team spirit and the ability to apply knowledge to solve the problem. Guidance and assessment of graduation design (paper) are attended with the participation of enterprises or industry experts.

\section{4) Support conditions}

Reference [5] analyzed the importance of enterpriseacademia cooperation on the education of engineering application-oriented students. The university should cooperate with the enterprise to build internship and training platform, and provide students with a platform to participate in engineering practice in the teaching process.

\section{The Construction of Teaching Staff}

In the engineering accreditation standards, some requirements about the quality and quantity of teachers are proposed [6]. First, the number of teachers can meet the teaching needs, the reasonable structure of teaching staff, and there are enterprises or industry experts as part-time teachers. Second, teachers should have sufficient teaching ability, professional level, engineering experience, communication skills, career development ability, also can carry out engineering practice research and participate in academic exchanges. The teacher's engineering background should be able to meet the needs of professional teaching. Third, teachers should have enough time and energy to devote to undergraduate teaching and student guidance, and actively participate in teaching research and reform. Fourth, teachers can provide guidance, counseling and services for the students and enough guidance for the students' career planning. Fifth, teachers should know exactly what they are responsible for in the process of teaching quality improvement and constantly improve their work.

\section{Students' International Vision and International Communication Ability}

One of the aims of engineering accreditation is to encourage universities to develop engineering graduates with international competitiveness. China's participation in the Washington Accord means that engineering education graduates in China are given a "pass" to apply for professional qualification across borders. But the bigger the chance means the bigger the challenge. In the face of competition from college graduates from all over the world, we should focus on developing students' international vision and improving their international competitiveness in the future.

In China, the biggest problem that graduates may meet when they enter foreign companies, is not the lack of professional knowledge, but is the language problems. Although English courses have been offered since primary 
school, the English used in the work has often involved many words about engineering. Therefore, it is necessary to provide English course for engineering in the process of undergraduate teaching. Combining English with professional knowledge can train the students' foreign language ability, on the other hand, students can learn about the latest developments in the international industry. Colleges and universities can also arrange the professor from foreign universities to give lectures and take this opportunity to develop in-depth exchange and cooperation with foreign universities. If there are conditions, colleges and universities can provide students with opportunities to study abroad and communicate, so that students can feel the different education mode more intuitively and open the students' international vision.

\section{CONCLUSIONS}

Engineering accreditation is an important foundation for building international mutual recognition of engineering education and engineer qualification. China's participation in the Washington Accord means that China engineering education accreditation is recognized by other signatories. At the same time, we also need to take Washington Accord as an opportunity to promote the reforms of education and teaching in universities. Some requirements about graduate attributes, teacher quality, training objectives, engineering practice and other aspects are summarized in the engineering accreditation standards, and these requirements are also the direction of college teaching reform. Some strategies and measures are proposed in this paper. Fox example, the integration of existing professional assessment and engineering accreditation.
Graduates should not only have a solid professional knowledge, but also have an understanding of professional and ethical responsibility and an ability to communicate effectively. In the face of competition from college graduates from all over the world, we should focus on developing students' international vision and improving their international competitiveness in the future.

\section{ACKNOWLEDGMENT}

The research is supported by Teachers' Teaching Development Research Project of University of Shanghai for Science and Technology.

\section{REFERENCES}

[1] http://www.ceeaa.org.cn

[2] http://www.ieagreements.org/accords/acknowledgements-accords/

[3] Chen Wu, Wang Deng Yu, "The only way to the professional development of civil engineering from assessment to accreditation," Higher Education of Sciences, vol. 3, pp. 72-77, 2017 (In Chinese).

[4] http://www.mohurd.gov.cn

[5] Chu Chaomei, Zhu Jianmin, "Exploration and practice of training engineering application-oriented students through enterprise-academia cooperation," Journal of University of Shanghai for Science and Technology, vol. 35, pp. 72-75, Mar. 2013 (In Chinese).

[6] Hu Wenlong, "Difficulties and emphases university teachers faced with on the background of professional accreditation of engineering," Research in Higher Education of Engineering, vol. 1, pp. 73-78, 2015 (In Chinese). 